\title{
Seasonal distribution and production of phytoplankton in the southern Kattegat
}

\author{
Katherine Richardson, Alice Christoffersen
}

Danish Institute for Fisheries and Marine Research, Charlottenlund Castle, DK-2920 Charlottenlund, Denmark

\begin{abstract}
The seasonal distributions of chlorophyll a and primary production throughout the water column were examined at a fixed station in the southern Kattegat. The most intensive data collection was in 1989 when the station was visited 55 times. Less intensive data collection was also carried out in 1988 and 1990. Surface chlorophyll distributions indicate the presence of a spring and autumn-winter 'bloom' in surface waters and relatively low chlorophyll a concentrations $\left(<2 \mu \mathrm{gl}^{-1}\right)$ in the surface mixed layer during summer. Phytoplankton in surface waters during summer (mid-May to ca 1 October) appear to be nutrient limited. From mid July until ca 1 October, the entire euphotic zone appears to be nutrient depleted. The highest chlorophyll concentrations observed during the spring bloom are associated with frontal waters separating the Kattegat and waters of the Baltic outflow. From the period immediately following the spring bloom until ca 1 September, the highest chlorophyll concentrations were observed in association with the pycnocline (nutriciline). During late spring and early summer, the pycnocline usually occurs at a depth of between ca 10 and $20 \mathrm{~m}$. The phytoplankton associated with the pycnocline during this period are usually photosynthetically active even at the photon flux densities encountered at the pycnocline. Thus, significant primary production occurs in this subsurface layer In 1989, total annual primary production at the study station was calculated to be ca $290 \mathrm{~g} \mathrm{C} \mathrm{m}^{-2}$ Approximately $19 \%$ of this production is estimated to occur during the spring bloom while on the order of $30 \%$ of the total is estimated to take place in subsurface phytoplankton populations during summer.
\end{abstract}

\section{INTRODUCTION}

The more or less annual hypoxia and anoxia events recorded in the southern Kattegat and Belt Seas during the 1980 s have led to considerable speculation as to the magnitude of the production of organic material in these waters. Until now, however, most studies of pelagic production and turnover in the open waters of this region have been carried out over limited time periods (i.e. Nicolajsen et al. 1983, Astheimer \& Haardt 1984, Richardson 1985, Nielsen et al. 1990). Studies examining annual patterns (i.e. Nicolaisen \& Christensen 1986) have largely been concerned with biomass and not production distribution.

All of the studies mentioned above have indicated the presence of a subsurface chlorophyll peak during part or all of the investigation period. Where hydrographic data have been presented (Richardson 1985, Nicolaisen \& Christensen 1986, Nielsen et al. 1990), it is clear that this peak is associated with the pycnocline separating surface waters of relatively low salinity (of Baltic origin) and bottom waters of higher salinity (originating from the Skagerrak/North Sea). Although the presence of a subsurface chlorophyll peak in the Kattegat is a well-known phenomenon, none of the studies carried out to date have addressed the question of what role subsurface phytoplankton peaks may play in the total production occurring in this region.

The study reported here is part of a research initiative supported by the Danish Ministry of the Environment and with the goal of describing processes leading to hypoxia/anoxia in Danish waters. The specific purpose of this particular project was to estimate the total annual primary production occurring in the Kattegat during a given year and to describe seasonal patterns in the distribution and production of phytoplankton in this region.

\section{MATERIALS AND METHODS}

Chlorophyll a and primary production determinations were made throughout the water column at a fixed station in the southern Kattegat $\left(56^{\circ} 11^{\prime} \mathrm{N}\right.$; $12^{\circ} 04^{\prime}$ E) from 1988 until 1990. The most intensive data collection was carried out in 1989 when phytoplankton 
studies were conducted on 55 visits to the station. These visits occurred at intervals of ca 2 wk throughout the year. In addition, 2 'intensive' sampling periods of ca 3 wk duration where the station was sampled every day (weather permitting) were carried out in 1989. Less intensive sampling was carried out in 1988 and 1990. Data from these years are, however, drawn upon in order to examine whether the seasonal pattern in phytoplankton distribution/activity identified for 1989 can be considered as typical for this area.

In addition to data collected on routine visits to the fixed station, data collected on an RV 'Dana' (Danish Fisheries Ministry) cruise in the Kattegat during March 1990 are included here. All methods used on RV 'Dana' were identical to those employed on routine visits to the fixed station with the exception of the determination of salinity and temperature throughout the water column. On routine station visits, these parameters were determined using a Salinity-Temperature Bridge (Type M.C.5, Electronic Switchgear (London) Ltd). Onboard RV 'Dana' salinity (\%o) and temperature (\%) were recorded using a Niel Brown CTD. Light attenuation through the water column was determined on all stations/visits. Inorganic nutrient determinations were made after the methods outlined in Grasshoff (1976).

Chlorophyll a extractions (90\% acetone) were carried out at 3 to 5 different depths (chosen on the basis of a fluorescence profile created using a $Q$ Instruments fluorometer) after the Lorenzen method (Strickland \& Parsons 1972). In addition to the wavelengths recommended in the Lorenzen method, absorption was measured at $480 \mathrm{~nm}$ on the acetone extracts. The $480 / 665$ ratio (corrected for absorption at $750 \mathrm{~nm}$ ) was then used as a qualitative indicator of nutrient (nitrogen) depletion in the phytoplankton community (see Heath et al. 1990).

Primary production incubations were carried out in glass scintillation vials (with plastic lined caps). Samples for incubations ( $9 \mathrm{ml}$ per scintillation vial) were taken from 2 or 3 depths in the water column using a 301 Niskin bottle. Surface (ca $2.5 \mathrm{~m}$ ) and pycnocline (or mid-water column) samples were always taken. In some cases, a sample was also taken below the pycnocline. In 1988, 2 types of incubations were carried out: in the first, 6 replicate samples were returned to the collection depth and incubated for 2 to $3 \mathrm{~h}$. The second method and that used in later years involved using a natural light incubator, cooled by running surface seawater and positioned on the ship's deck. The incubator was divided into compartments covered by glass neutral density filters so that incubations were carried out at 6 different photon flux densities and in darkness. Approximately $0.75 \mu \mathrm{Ci}{ }^{14} \mathrm{CO}_{2}$ (International Agency for ${ }^{14} \mathrm{C}$ Determination, Hørsholm, Denmark) was added to each vial at the beginning of the incubation and 3 replicates were incubated ( 2 to 3 h) at each photon flux density. The ${ }^{14} \mathrm{C}$ addition was checked by taking $50 \mu \mathrm{l}$ subsamples of the incubation medium and adding them to $0.5 \mathrm{ml} \beta$-phenylethylamine. These samples were stored for later counting. Incubations were stopped by adding $0.1 \mathrm{ml} 2 \mathrm{~N} \mathrm{HCl}$ and placing vials in darkness. Incident light was recorded at 10 min intervals throughout the incubation period using a cosine collector.

Upon return to the laboratory, samples were bubbled (air; $30 \mathrm{~min}$ ) to remove excess ${ }^{14} \mathrm{CO}_{2}$ and scintillation fluid (Instagel) was added. Counting of associated radioactivity was carried out by the International Agency for ${ }^{14} \mathrm{C}$ Determination. Incubation data was converted to photosynthesis vs photon flux density (P vs I) curves after guidelines presented in Richardson (1987)

Although it is assumed that the ${ }^{14} \mathrm{C}$ method measures something between net and gross photosynthesis, no correction is made here for respiration. The rationale for not including a respiration correction is the uncertainty about what the ${ }^{14} \mathrm{C}$ method actually measures (see Peterson 1980) and gradually accumulating evidence that the ${ }^{14} \mathrm{C}$ method may, in some cases, underestimate net photosynthesis (Li \& Goldman 1981, Richardson et al. 1984, Jespersen, A. M. unpubl.). Given these uncertainties, it seems superfluous to make a correction of uncertain magnitude but probably on the order of $10 \%$. In all events, ${ }^{14} \mathrm{C}$ production data can only give a rough estimate of the rates of the processes being examined.

As the method used to calculate potential daily production has been shown to significantly affect the results obtained (Richardson 1991), some detail of the model used here is presented. The model used employs actual daylength for the 15 th day of each month. Light is assumed to proportionally increase and decrease throughout the day after the same pattern every month. However, the average maximum irradiation at midday varies from month to month. A matrix describing underwater light climate for every hour of the day at $1 \mathrm{~m}$ intervals is then generated using a light attenuation coefficient $(k)$ obtanned after the Lambert-Beer Law. The shapes of P vs I curves obtained from the different depths are assumed to be representative for the water masses from which samples were taken (as defined by the hydrographic profile made at the station). However, $\mathrm{P}_{\max }$ was assumed to be a linear function of chlorophyll concentration within the different water masses. Fluorescence profiles were converted to chlorophyll concentrations at each $1 \mathrm{~m}$ depth interval. Applying the light matrix to the $P$ vs I curve and $P_{\max }$ assigned to each depth yields an estimate for daily production.

In order to calculate annual production, a weekly 
average was determined for those periods in which more than 1 sample per week was collected. Where only 1 sample was collected, this was assumed to be representative for the days in that week and, in weeks where no samples were taken, a daily primary production value was assigned via extrapolation. The daily values for each week were then averaged and multiplied by 365 to give annual production.

\section{RESULTS}

The distribution of chlorophyll $a$ in surface waters $(2.5 \mathrm{~m})$ is shown for 1989 in Fig. 1. A pronounced spring bloom can be seen to occur during Weeks 11 to 14 (corresponding to the last 3 wk of March and first week in April). During the summer months, the chlorophyll concentration in surface waters was generally under $2 \mu \mathrm{g}^{-1}$. There may have been a slight increase in surface chlorophyll concentrations in connection with a Ceratium bloom (dominating species C. furca, C. tripos, and C. fusus) around Week 35 (ca 1 September). However, in this period, sampling was more intensive than in the surrounding period and the statistical significance of the apparent increase cannot be determined. Chlorophyll concentrations in surface waters began to rise around Week 45 (mid-November) and reached a value of over $5 \mu \mathrm{g} \mathrm{l}^{-1}$ by Week 51 (midDecember).

The highest concentrations of chlorophyll a recorded in connection with the spring bloom were seen to be associated with the passage of a front by the fixed station as evidenced by the presence of lower salinity surface water (Fig. 2). From the salinity distribution, it can be concluded that this front marks the boundary of the Baltic outflow.

From 24 to 27 March 1990, CTD and surface chlorophyll data were collected at 19 stations in the Kattegat between $55^{\circ} 50^{\prime}$ and $57^{\circ} 00^{\prime} \mathrm{N}$ while the spring bloom was underway. Plotting surface chlorophyll concentrations as a function of surface salinity (Fig. 3) indicates that elevated chlorophyll concentrations were associated with the transition waters between the Kattegat and the lower salinity Baltic outflow and not the Baltic outflow itself.

On 26 March 1990 (Week 13), 4 stations on a line very nearly intersecting the position of the fixed station were studied in detail. The surface chlorophyll distributions and salinity distributions through the water column are shown in Fig. $4 \mathrm{a}$, b. Stn 2 corresponds most closely to the fixed sampling station. As for 1989, it can be seen that the highest chlorophyll concentrations were associated with frontal waters. However, the front did not extend to the fixed sampling station at this time. The failure of the front to extend over the fixed sampling position may explain the lower surface chlorophyll concentrations observed at the fixed station in 1990 as compared to 1989 (highest in $1990=5.4{\mu \mathrm{gl}^{-1}}^{-1}$ ). Calculated daily primary productivity estimates at the fixed station are correspondingly lower in 1990 than in 1989. The highest value recorded in the 1990 spring bloom was $909 \mathrm{mg} \mathrm{m}^{-2} \mathrm{~d}^{-1}$ (Table 1). It should be noted, however, that sampling during the spring bloom in 1990 was not as intensive as in 1989. The spring bloom period was not sampled in 1988 .

The chlorophyll a concentration at $2.5 \mathrm{~m}$ divided by

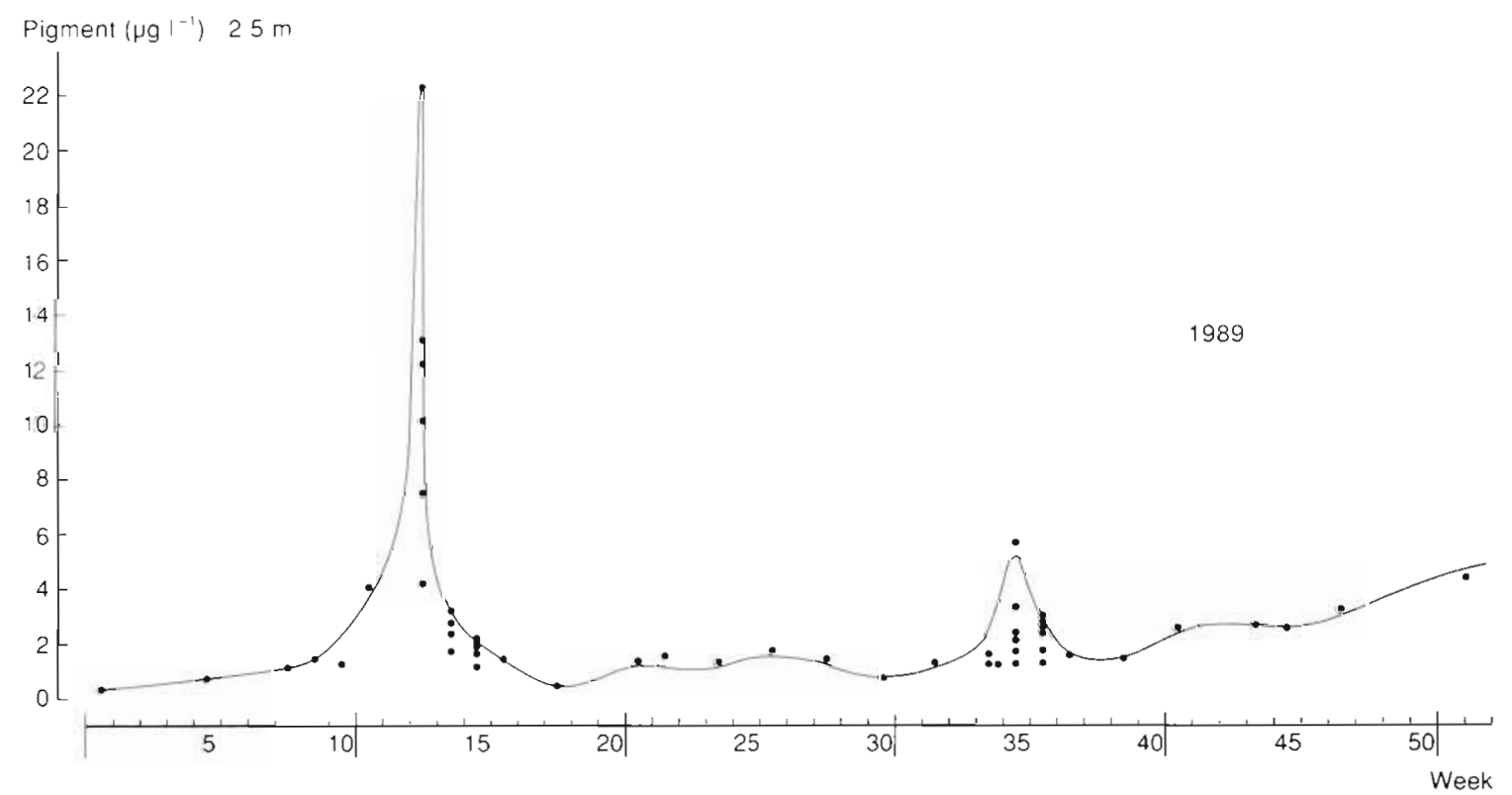

Fig. 1. Distribution of chlorophyll $a\left(\mu \mathrm{g} \mathrm{l}^{-1}\right)$ in surface water $(2.5 \mathrm{~m})$ at a fixed station in the southern Kattegat in 1989 


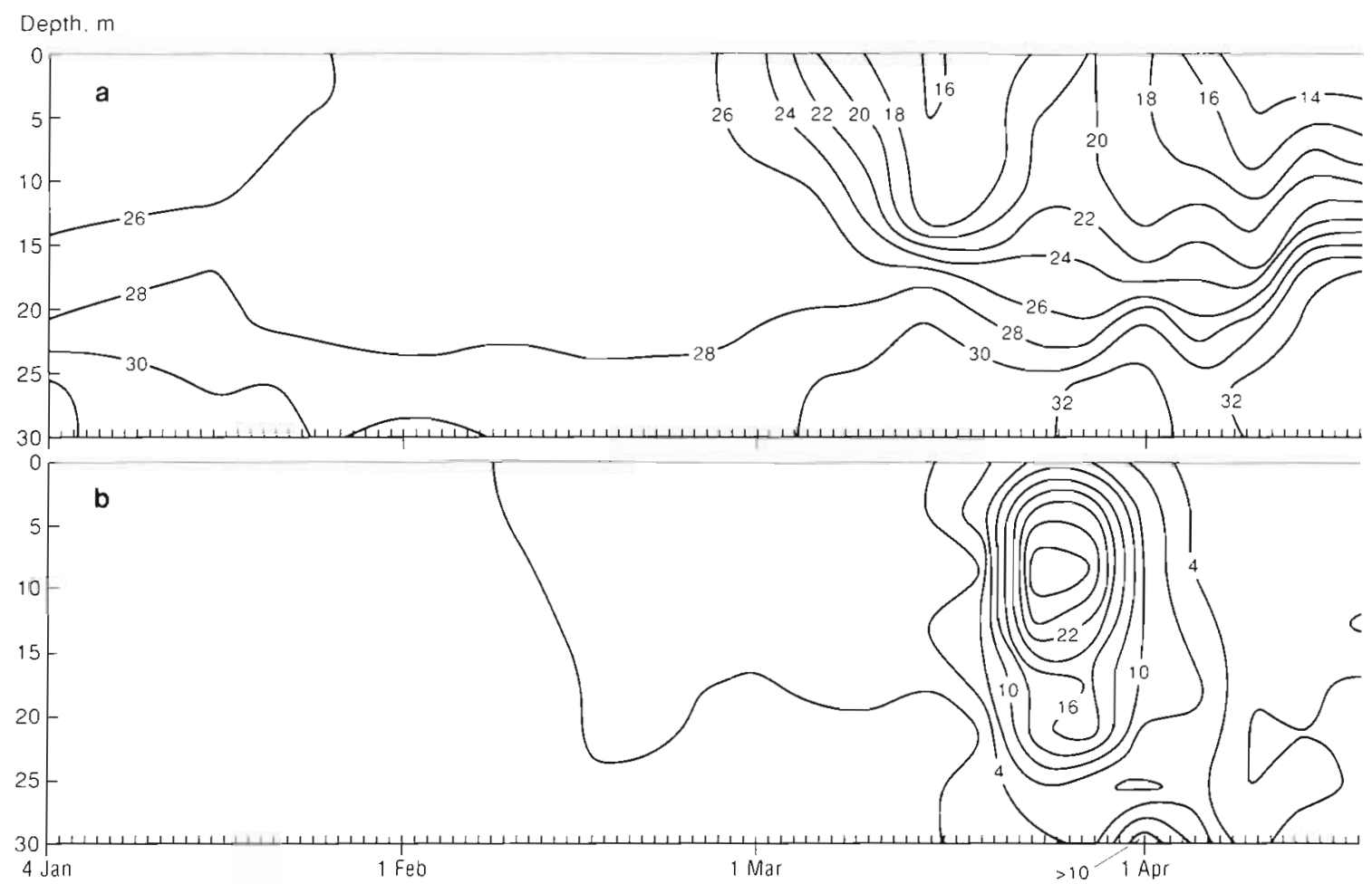

Fig. 2. Distribution of (a) salinity $\left(S_{;} \%\right)$ and (b) chlorophyll a $\left(\mu \mathrm{gl}^{-1}\right)$ throughout the water column at a fixed station in the southern Kattegat in the period surrounding and during the spring bloom in 1989

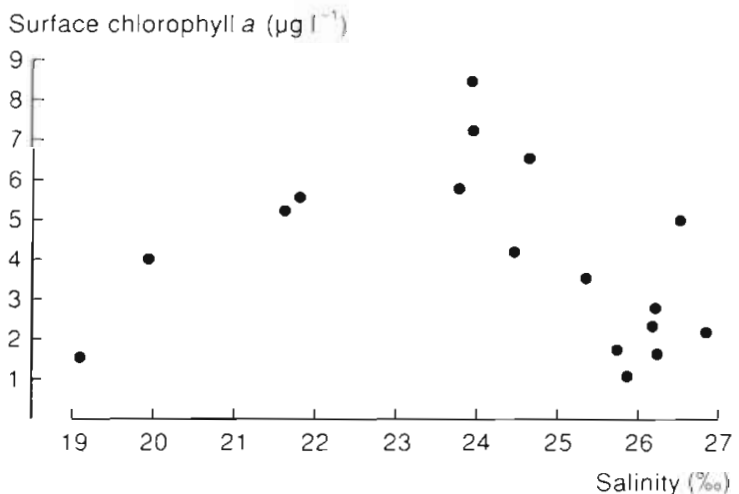

Fig. 3. Chlorophyll a $\left(\mu \mathrm{g} \mathrm{l}^{-1}\right)$ in surface $(2.5 \mathrm{~m})$ waters expressed as a function of salinity of surface waters on all stations south of $57^{\circ} 00^{\prime} \mathrm{N}$ and north of $55^{\circ} 50^{\prime} \mathrm{N}$ on RV 'Dana'

Cruise 90/3 in the Kattegat from 24 to 27 March 1990

the highest chlorophyll concentration recorded in the water column (determined by extraction not fluorescence) is plotted in Fig. 5. From the time of the end of the spring bloom (Week 14 to 15) until the Ceratium bloom at the beginning of September, the maximum chlorophyll concentrations were associated with subsurface chlorophyll peaks (chlorophyll at $2.5 \mathrm{~m} /$ highest chlorophyll concentration $<1$ ). As a rule, these subsurface chlorophyll peaks were associated with isopycnals.

Fourteen visits carried out from 28 May to 16 June
1988 at the fixed station also indicated the presence of a subsurface chlorophyll peak associated with isopycnals on all but one visit. During both years, the magnitude of the peak could vary considerably from day to day. During the intensive sampling in 1988, the chlorophyll concentration in the subsurface peak varied from $10.2 \mathrm{Mg} \mathrm{l}^{-1}$ (when Chrysochromulina polylepis was present at the pycnocline) to $0.4 \mu \mathrm{g} \mathrm{l}^{-1}$. Surface $(2.5 \mathrm{~m})$ chlorophyll a concentrations varied from 0.2 to $0.7 \mu \mathrm{g} \mathrm{l}^{-1}$ during the same period.

Subsurface chlorophyll peaks could contribute significantly to the primary production occurring at the fixed station. Fig. 6 shows the distribution of primary production through the water column on 31 May 1988 (when Chrysochromulina polylepis was present at the pycnocline). This profile was generated using incubator data (where a P vs I curve is generated and total daily production can be calculated). However, in situ incubations indicated that hourly production rates at $10.5 \mathrm{~m}$ were up to $30 \times$ greater than at $2.5 \mathrm{~m}$ under the C. polylepis bloom. Similar profiles were found to occur from April to October in 1989. No primary production data exists from August 1989. However, chlorophyll distributions during this period (Weeks 31 to 35 ) indicate the presence of substantial chlorophyll peaks on a number of occasions (see Fig. 5). Thus it seems likely that considerable production was also occurring deep in the water column during the month 

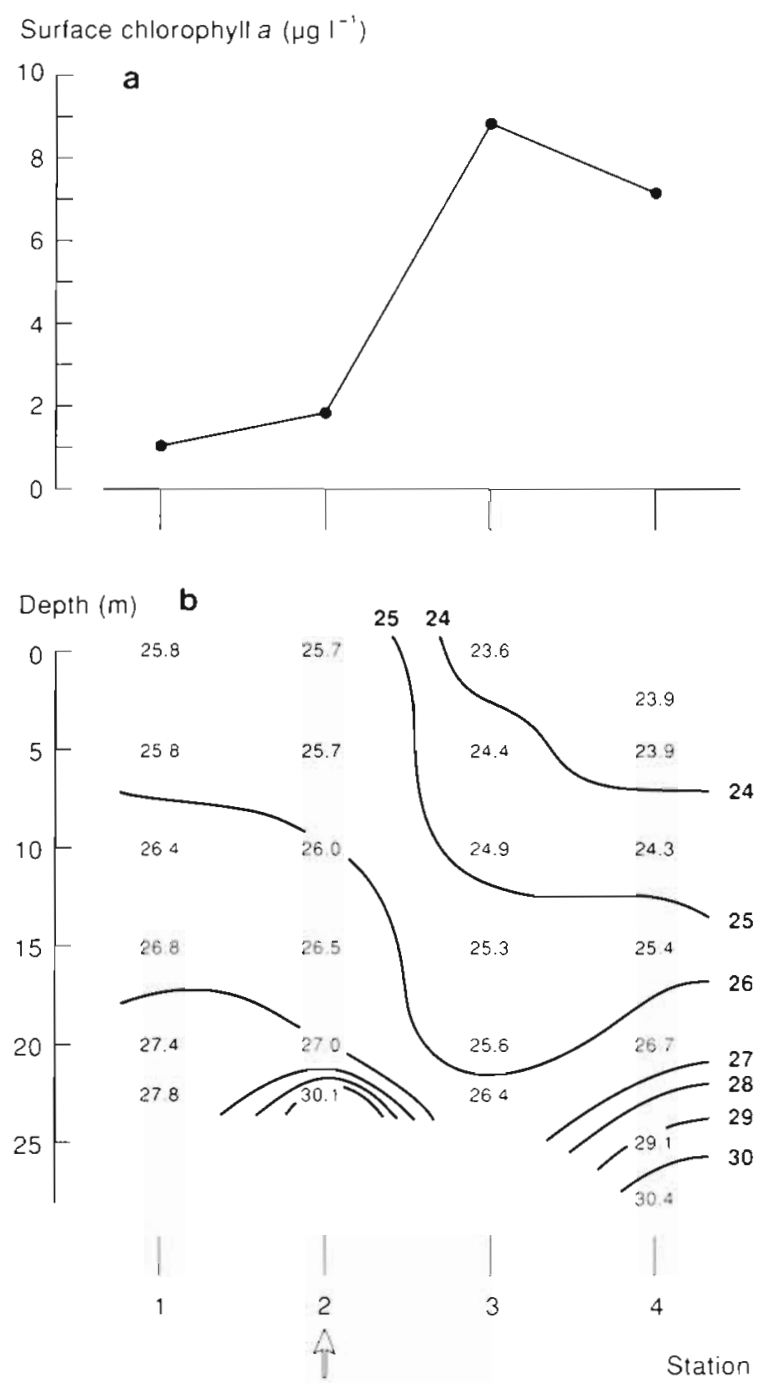

Fig. 4. (a) Surface chlorophyll $(2.5 \mathrm{~m})$ at 4 stations on a southwest-northeast transect in the southern Kattegat sampled on 26 March 1990. (b) Salinity distributions through the water column on same transect. Stn $2\left(56^{\circ} 12^{\prime} N_{i} 12^{\circ} 03^{\prime} E\right)$ lies closest to the fixed sampling position

of August. Support for this argument can be found in the 1990 data where 5 primary production measurements were made during August.

On all sampling days, a productive phytoplankton peak was observed at the pycnocline. Measurements made on 6 and 24 September 1990 also showed the presence of a subsurface phytoplankton peak which contributed substantially to total water column production.

The measured distribution of primary production at the fixed station in 1989 is shown in Fig. 7. Here, the importance of subsurface chlorophyll peaks in primary production can be seen in that relatively high primary production is maintained in the period following the spring bloom until between Weeks 28 and 30 (middle
Table 1. Primary production (pp) estimates at the fixed position in 1990

\begin{tabular}{|rcr|}
\hline \multicolumn{1}{|c}{ Date } & Week & $\begin{array}{c}\mathrm{pp} \\
\left(\mathrm{mg} \mathrm{C} \mathrm{m}^{-2} \mathrm{~d}^{-1}\right)\end{array}$ \\
\hline $29 \mathrm{Mar}$ & 13 & 287 \\
$2 \mathrm{Apr}$ & 14 & 909 \\
$15 \mathrm{Aug}$ & 33 & 359 \\
$17 \mathrm{Aug}$ & 33 & 668 \\
$22 \mathrm{Aug}$ & 34 & 1820 \\
$27 \mathrm{Aug}$ & 35 & 139 \\
$29 \mathrm{Aug}$ & 35 & 2054 \\
$6 \mathrm{Sep}$ & 36 & 535 \\
$24 \mathrm{Sep}$ & 39 & 982 \\
$4 \mathrm{Oct}$ & 40 & 188 \\
$11 \mathrm{Oct}$ & 41 & 531 \\
$30 \mathrm{Oct}$ & 44 & 259 \\
$13 \mathrm{Nov}$ & 46 & 142 \\
$6 \mathrm{Dec}$ & 49 & 223 \\
\hline
\end{tabular}

to end of July). The intensive sampling between Weeks 22 and 24 (May-June) in 1988 also indicated the importance of subsurface chlorophyll peaks in the contribution to total daily primary production. During this time, considerable variation in estimated daily production was recorded (209 to $2796 \mathrm{mg} \mathrm{C} \mathrm{m}^{-2} \mathrm{~d}^{-1}$ ). This variation reflects the variability recorded in the magnitude of the subsurface peak discussed above. The average daily primary production in this period was $916 \mathrm{mg} \mathrm{C} \mathrm{m} \mathrm{m}^{-2} \mathrm{~d}^{-1}$.

The $480 / 665$ absorption ratio on chlorophyll extracts is shown in Fig. 8. This ratio has been shown to be qualitatively related to the nutrient status (carbon/nitrogen ratio) of phytoplankton (Watson \& Osborne 1979, Heath et al. 1990). Values approaching and exceeding 2.0 suggest nutrient (nitrogen) limitation. The increase in $480 / 665$ ratio from 1.1 to over 2.0 in surface waters in the weeks following the spring bloom suggests the onset of nitrogen limitation in surface waters following the spring bloom. Nitrate and silicate distributions throughout the water column at the fixed station during the period surrounding the spring bloom in 1989 are shown in Fig. 9. Nitrate was no longer detectable in surface waters from Week 13 (28 March) while silicate was detectable throughout this period. Week 13 was also the point at which subsurface chlorophyll peaks were first observed in 1989 (Fig. 5).

The 480/665 ratio indicates nutrient-depleted phytoplankton throughout the water column from ca Week 28 to ca Week 39. Nutrient concentrations through the water column at the fixed station during the summer months are, unfortunately, not available. However, routine nutrient sampling in the southern Kattegat is carried out by Danmarks Miljøundersøgelser (Danish National Environmental Research Institute) every year at various times during the year. The average bottom 


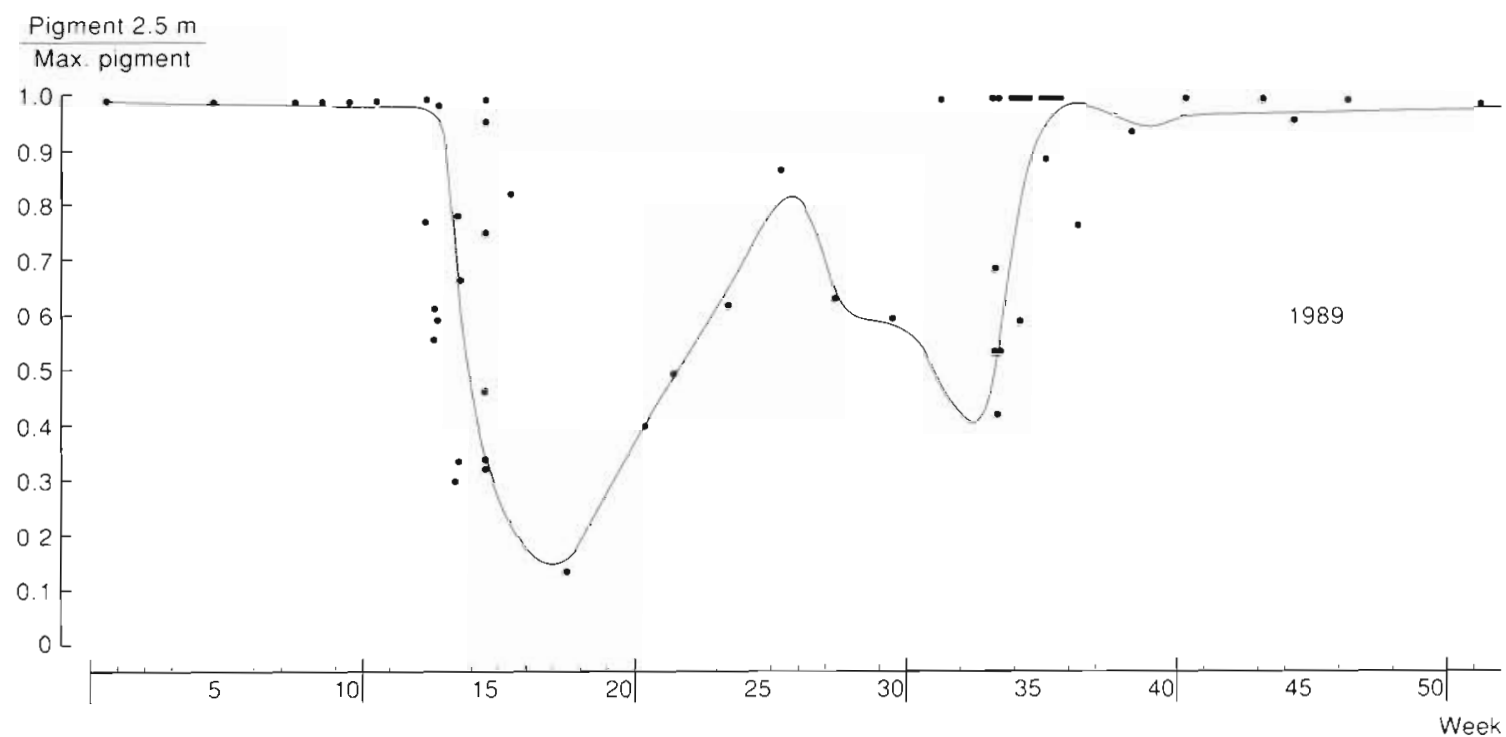

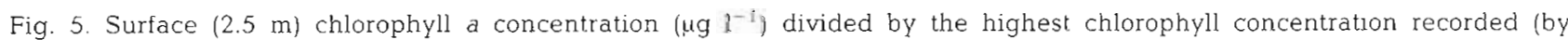
extraction) in the water column

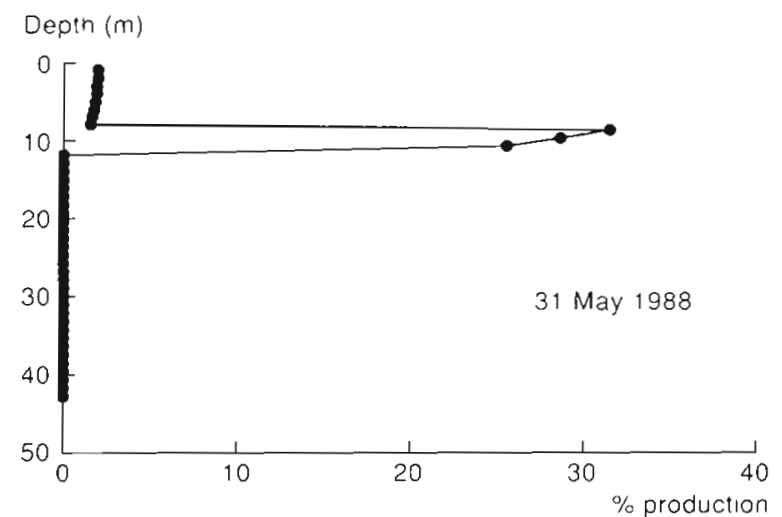

Fig. 6. Distribution of primary production through the water column on 31 May 1988. At this time, Chrysochromulina polylepsis dominated at the pycnocline. Total primary production for this date was calculated to be $2796 \mathrm{mg} \mathrm{C} \mathrm{m}^{-2} \mathrm{~d}^{-1}$

concentration of nitrate observed in the southern Kattegat during their monitoring cruise from 10 to $14 \mathrm{July}$ 1989 was 12.6 umol $1^{-1}(\mathrm{SD}=2.9, \mathrm{n}=5)$. On their August cruise, this value was $9.6 \mu \mathrm{g} \mathrm{mol} \mathrm{l}^{-1}(\mathrm{SD}=1.8 \mathrm{n}=5)$.

In Fig. 10, the average nitrate concentrations in August in near-bottom waters for stations with a depth of over $20 \mathrm{~m}$ found in the data base of the International Council for Exploration of the Seas for the years 1971 to 1987 are plotted. The stations were selected from 2 areas in the Southern Kattegat $\left(55^{\circ} 55^{\prime}\right.$ to $56^{\circ} 50^{\prime} \mathrm{N}_{\text {; }}$ $11^{\circ} 30^{\prime}$ to $12^{\circ} 20^{\prime} \mathrm{E}$, and $55^{\circ} 55^{\prime}$ to $56^{\circ} 35^{\prime} \mathrm{N}_{i} 10^{\circ} 40^{\prime}$ to $11^{\circ} 30^{\prime} \mathrm{E}$ ). It can be seen that nitrate concentrations in near-bottom waters appear from the limited data available) to have increased from $\leq 2.0 \mu \mathrm{mol} \mathrm{l}^{-1}$ in the early $1970 \mathrm{~s}$ to $>6 \mathrm{mmol}^{-1}$ in recent years and that the near-bottom nitrate values observed in 1989 fit with the trend observed in recent years.
From near-bottom mitrate concentrations there is no reason to suspect nitrogen depletion in bottom waters as suggested by the $480 / 665$ ratio (Fig. 8). However, the measured light extinction coefficients for the water column at the fixed station indicate that the $1 \%$ light penetration level during July and August lies between ca 15 and $18 \mathrm{~m}$. Examination of nitrate concentrations at 15 and $20 \mathrm{~m}$ at a station near the fixed position from May to September 1989 (Table 2) indicates that nitrate was not detectable at $15 \mathrm{~m}$ in August and only very low concentrations were recorded at $20 \mathrm{~m}$. This suggests that the nutriciline lay near or below the $1 \%$ light penetration level in late summer 1989. Lack of nutrients in the euphotic zone can explain both the apparent nitrogen limitation of the phytoplankton in the water column (Fig. 8) and the decline in primary production (Fig. 7) observed at the fixed position in late summer 1989

From Danmarks Miljøundersøgelser it was also possible to obtain a time-series of data on nitrate concentrations at 15 and $20 \mathrm{~m}$ during July and August at a station located ca $30 \mathrm{n}$ mile north of the fixed position (Table 3). It can be seen from the table that low or nondetectable concentrations of nitrate are often found at $15 \mathrm{~m}$ during both July and August. Concentrations at $20 \mathrm{~m}$ can be high in July but, with the exception of 1983, fall to below 1.0 umol $1^{-1}$ by August. Thus, it would appear that, with respect to the depth of the nutricline, 1989 appears to have followed the pattern observed in recent years.

A fall in total daily production (Fig. 7) occurs after Week 28 which coincides with the onset of the period in. which the nutricline is suspected to approach or fall below the $1 \%$ light penetration depth. Primary produc- 


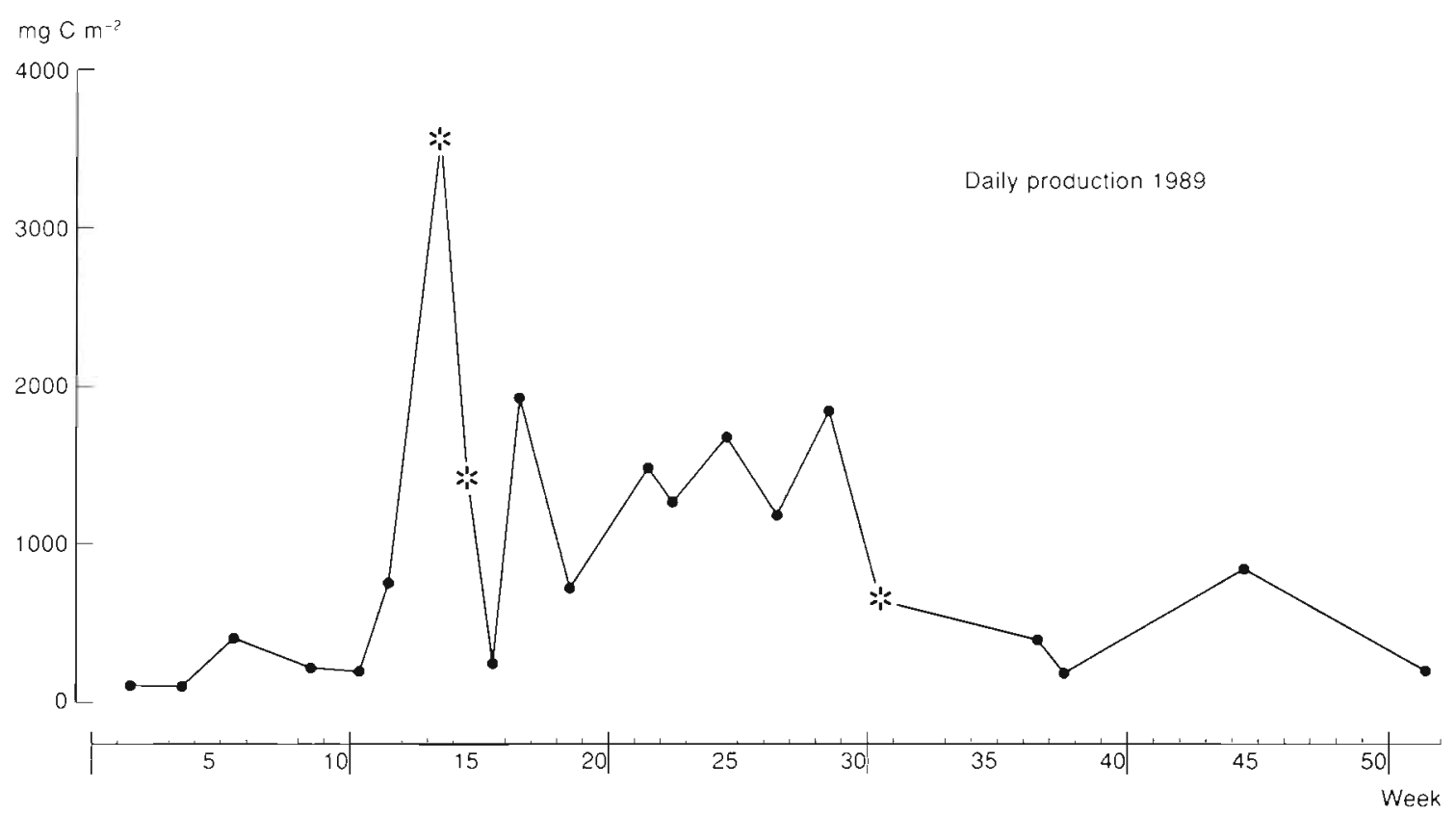

Fig. 7. Daily primary production at a fixed station in the southern Kattegat during 1989. Stars represent weeks in which more than 1 sample was taken

tion begins to increase again in the period Weeks 37 to 44 which coincides with the period in which nutrient depletion apparently ends (Fig. 8).

Although sampling in the autumn of 1989 was less frequent than during the spring, the order of magnitude of the estimated primary production agrees well with that recorded in 1988 when more intensive sampling was carried out. In 1988, 15 samples were taken at the fixed station between 24 October and 11 November (Weeks 43 to 45 ). The average daily primary production for this period was $923 \mathrm{mg} \mathrm{C} \mathrm{m}^{-2} \mathrm{~d}^{-1}$ which is similar to that recorded in Week 45 in 1989 (see Fig. 7). The October/November measurements made in 1990 were somewhat lower than those recorded in 1988 and 1989 (see Table 1). However, the general primary production estimates observed during the last half of 1990 fall within the same range as those recorded in 1989.

The primary production value recorded in Week 51 in 1989 seems low in relation to the chlorophyll values recorded at this time (Fig. 1). It should be noted, however, that insolation on the sampling day was extremely low and the P vs I curves generated in the natural light incubator indicate that photosynthesis was not saturated. Thus, the maximum rate of photosynthesis is probably underestimated in the calculation of daily primary production.

The total daily primary production occurring at the fixed station in 1989 is estimated in this study to have been ca $290 \mathrm{~g} \mathrm{C} \mathrm{m}^{-2}$. While this value will vary from

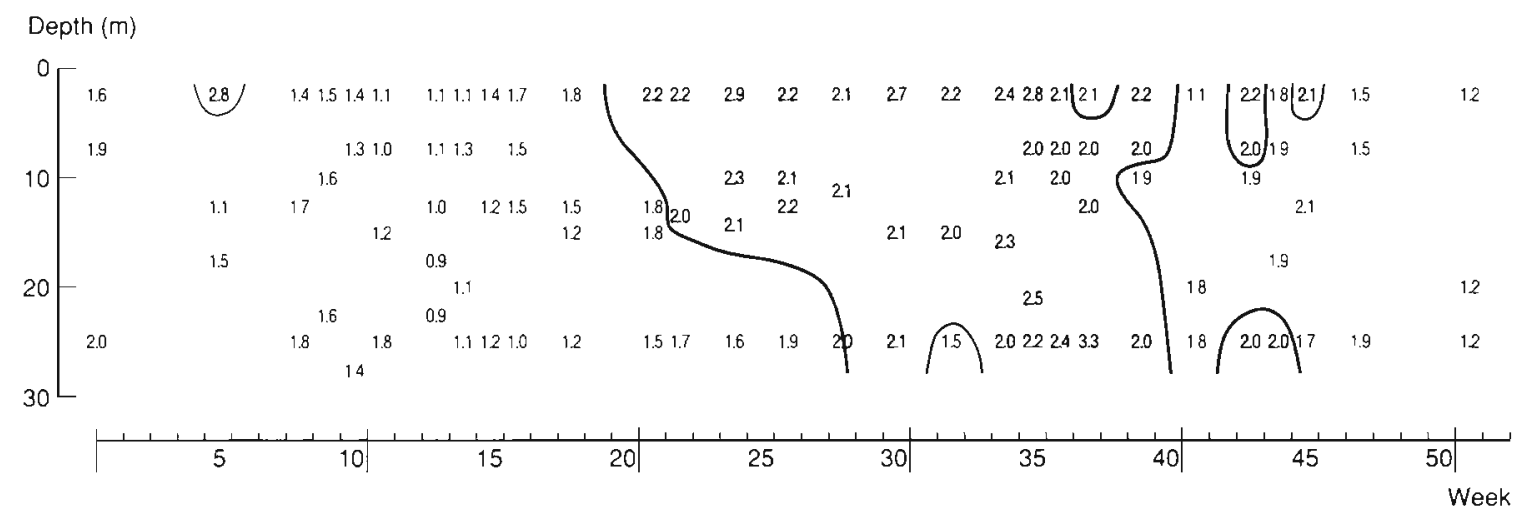

Fig. 8. Distribution of the $480 / 665$ absorption ratio through the water column at a fixed station in the southern Kattegat in 1989 . Values of over ca 2.0 (shaded) indicate a phytoplankton population that is nutrient (nitrogen) depleted (see Heath et al. 1990) 

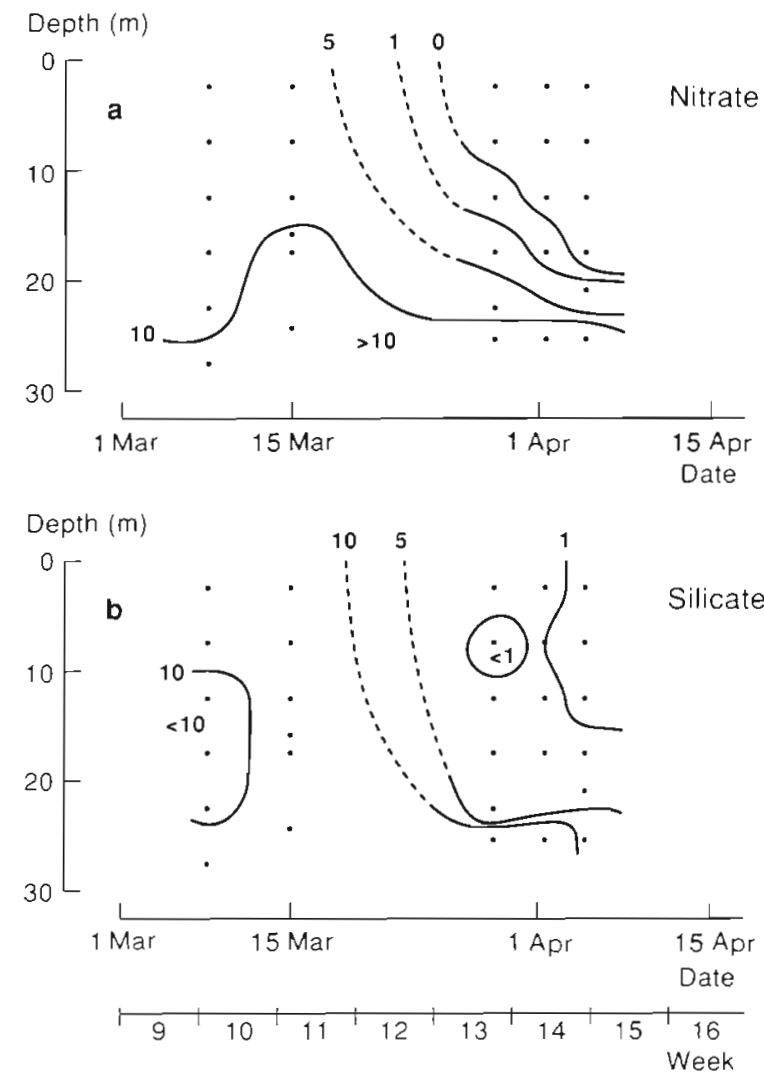

Fig. 9. (a) Nitrate (umol $\mathrm{l}^{-1}$ ) and (b) silicate (umol $\mathrm{l}^{-1}$ ) concentrations throughout the water column during the period of the spring bloom at a fixed station in the southern Kattegat in 1989

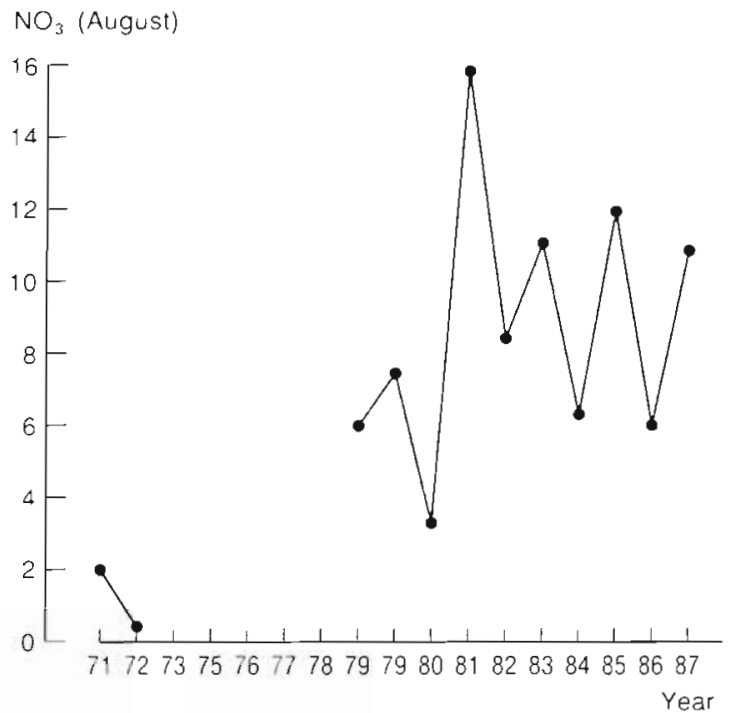

Fig. 10. Average nitrate (umol $\mathrm{1}^{-1}$ ) concentrations in nearbottom waters in the southern Kattegat in the period from 1971 to 1987 . Data is taken from the ICES database and includes stations with a depth of $>20 \mathrm{~m}$ located within $55^{\circ} 55^{\prime}$ to $56^{\circ} 50^{\prime} \mathrm{N}_{i} 11^{\circ} 30^{\prime}$ to $12^{\circ} 20^{\prime} \mathrm{E}$ or $55^{\circ} 55^{\prime}$ to $56^{\circ} 35^{\prime} \mathrm{N}: 10^{\circ} 40^{\prime}$ to $11^{\circ} 30^{\prime} \mathrm{E}$
Table 2. Nitrate concentrations ( $\mu \mathrm{mol} \mathrm{L}^{-1}$ ) at 15 and $20 \mathrm{~m}$ from May to September 1989 in the southern Kattegat $\left(56^{\circ} 10^{\prime} \mathrm{N}\right.$; $\left.211^{\circ} 48^{\prime} \mathrm{E}\right)$ near the fixed position $\left(56^{\circ} 11^{\prime} \mathrm{N} ; 2^{\circ} 04^{\prime} \mathrm{E}\right)$ discussed in the text. Data supplied by Danmarks Miljøundersøgelser

\begin{tabular}{rrrrr} 
& 29 May & 11 Jul & 14 Aug & 18 Sep \\
\hline $15 \mathrm{~m}$ & 0.2 & 0.5 & 0 & 0.3 \\
$20 \mathrm{~m}$ & 12.4 & 11.5 & 0.7 & 1.3 \\
\hline
\end{tabular}

Table 3. Nitrate concentrations $\left(\mu \mathrm{mol} \mathrm{l} \mathrm{l}^{-1}\right.$ ) at 15 and $20 \mathrm{~m}$ during July and August at a station in the southern Kattegat $\left(56^{\circ} 40^{\prime} \mathrm{N} ; 12^{\circ} 07^{\prime} \mathrm{E}\right)$ near the fixed position $\left(56^{\circ} 11^{\prime} \mathrm{N}_{i} 12^{\circ} 04^{\prime} \mathrm{E}\right)$ discussed in the text during the 1980 s. Data supplied by Danmarks Miljøundersøgelser

\begin{tabular}{|c|c|c|c|}
\hline Year & Depth & July & August \\
\hline \multirow[t]{2}{*}{1981} & $15 \mathrm{~m}$ & 0.5 & 0 \\
\hline & $20 \mathrm{~m}$ & 0.2 & 0.4 \\
\hline \multirow[t]{2}{*}{1982} & $15 \mathrm{~m}$ & 0 & 0 \\
\hline & $20 \mathrm{~m}$ & 0.7 & 0 \\
\hline \multirow[t]{2}{*}{1983} & $15 \mathrm{~m}$ & 0 & 0.1 \\
\hline & $20 \mathrm{~m}$ & 10.6 & 2.1 \\
\hline \multirow[t]{2}{*}{1984} & $15 \mathrm{~m}$ & 0.2 & 0 \\
\hline & $20 \mathrm{~m}$ & 0.1 & 0 \\
\hline \multirow[t]{2}{*}{1985} & $15 \mathrm{~m}$ & 0.1 & 0 \\
\hline & $20 \mathrm{~m}$ & 0.1 & 0.1 \\
\hline \multirow[t]{2}{*}{1986} & $15 \mathrm{~m}$ & 0.7 & 0 \\
\hline & $20 \mathrm{~m}$ & 1.9 & 0.5 \\
\hline \multirow[t]{2}{*}{1087} & $15 \mathrm{~m}$ & 0.1 & 0.5 \\
\hline & $20 \mathrm{~m}$ & 1.9 & 0.5 \\
\hline \multirow[t]{2}{*}{1988} & $15 \mathrm{~m}$ & No data & 0 \\
\hline & $20 \mathrm{~m}$ & No data & 0 \\
\hline \multirow[t]{2}{*}{1989} & $15 \mathrm{~m}$ & 0.5 & 0 \\
\hline & $20 \mathrm{~m}$ & 8.0 & 0 \\
\hline
\end{tabular}

year to year, comparison with data collected in 1988 and 1990 does not suggest that 1989 should have been atypical with respect to primary production rates.

The spring bloom occurred from Weeks 11 to 14 There was one measurement for daily primary production in Week 11 (772 $\left.\mathrm{mg} \mathrm{C} \mathrm{m} \mathrm{d}^{-1}\right)$. There were 5 measurements $\left(\overline{\mathrm{x}}=3614 \mathrm{mg} \mathrm{C} \mathrm{m}{ }^{-2} \mathrm{~d}^{-1}\right)$ for Week 13 and 4 in Week $14\left(\bar{x}=1417 \mathrm{mg} \mathrm{C} \mathrm{m}^{-2} \mathrm{~d}^{-1}\right)$. There were no measurements for Week 12 . However, we can estimate a value lying midway between that measured for Weeks 11 and 13 (2193 $\mathrm{mg} \mathrm{C} \mathrm{m} \mathrm{Cd}^{-1}$ ). Taking the average of the estimates of daily primary production for the 4 weeks and multiplying by $28 \mathrm{~d}$ indicates that ca $56 \mathrm{~g} \mathrm{C} \mathrm{m}^{2}$ were fixed during the spring bloom which corresponds to ca $19 \%$ of the total annual primary production occurring at this station. Estimating the contribution to total primary production by photosynthesis occurring in subsurface chlorophyll peaks is less straightforward due to (1) the large variability noted in 
the concentration of phytoplankton in the subsurface peaks and (2) the difficulty in accurately sampling the subsurface peaks which could occur from 1 to $2 \mathrm{~m}$ to ca $10 \mathrm{~m}$ depth. However, subsurface chlorophyll peaks were consistently observed in the period from ca Week 15 to 35 (see Fig. 5). On occasions, up to ca $90 \%$ of the total daily primary production was estimated to occur in the subsurface layers (see Fig. 6). However, when the subsurface peak was less pronounced, values of 30 to $40 \%$ of total water column production were estimated. If we conservatively estimate that $50 \%$ of total water column production occurs in subsurface phytoplankton peaks in the period from Weeks 15 to 35 , we can calculate that ca $87 \mathrm{~g} \mathrm{C} \mathrm{m}^{-2}$ were fixed in subsurface phytoplankton peaks in 1989. This corresponds to ca $30 \%$ of the total annual primary production occurring at this station.

\section{DISCUSSION AND CONCLUSIONS}

This study has demonstrated the relative importance of the primary production occurring in association with subsurface chorophyll peaks to the total primary production occurring at a fixed station in the southern Kattegat. For 1989, it is estimated that ca $19 \%$ of the total annual primary production occurring at this station took place during the spring bloom, while on the order of $30 \%$ of the total was fixed in association with subsurface chlorophyll peaks. It is possible that the primary production estimates reported here overestimate photosynthesis rates from pycnocline populations in that all incubations in 1989 were carried out at surface water temperatures (i.e. warmer than in situ at the pycnocline). Nevertheless, the observation in 1988 of in situ photosynthesis rates at the pycnocline of up to $30 \times$ greater than at $2.5 \mathrm{~m}$ during the Chrysochromulina polylepis bloom would argue for a substantial contribution by subsurface phytoplankton populations to total water column production.

These subsurface peaks are, as a rule, located at the pycnocline which during summer in the Kattegat usually coincides with the nutricline. Subsurface peaks dominate the distribution of chlorophyll a from the period immediately following the spring bloom (early April) to ca 1 September (Fig. 5). This period corresponds well to the period in which the $480 / 665$ absorption ratio on acetone extracts (see Heath et al. 1990) indicates nutrient-depleted phytoplankton in surface waters (Fig. 8). This suggests that the occurrence of subsurface phytoplankton populations is a response to nutrient-depleted surface waters in this region

Further evidence for this conclusion comes from the fall in daily primary production estimates observed after Week 28 (Fig. 7). From Week 28, the 480/665 ratio suggests that nutrient depletion extends throughout the euphotic zone. Data presented here suggest that nitrate is no longer available above the $1 \%$ light penetration level during mid-late summer.

In spite of the lower insolation rates, the daily primary production rate increases in the autumn (Fig. 7 and data from 1988) when $480 / 665$ ratio suggests that the phytoplankton population is no longer nutrient limited (Fig. 8).

The spring bloom in the study region appears to be most pronounced in the frontal region separating Kattegat waters and waters of the Baltic outflow (Fig. 2, 3 \& 4). The reason for this stimulation of the bloom in frontal waters in unknown and the distribution of major inorganic nutrients between the 2 water masses does not immediately offer an explanation. Routine monitoring cruises carried out by Danmarks Miljøundersøgelser (Gunni Æirtebjerg unpubl.) from 12 to 23 February and 12 to 22 March 1990 indicate that nitrate, silicate, and phosphate all occurred in measurable concentrations on both sides of the front on both cruises. (On the second cruise, the stations nearest the fixed position were sampled between 20 and 22 March.) On these cruises, nutrient concentrations were marginally higher in the Baltic outflow water than in surface Kattegat water (Baltic outflow: nitrate Feb/Mar = $7.7 / 1.9 \mu \mathrm{mol} \mathrm{l}^{-1}$, silicate $=6.8 / 1.9 \mu \mathrm{mol} \mathrm{l} l^{-1}$, phosphate $=0.9 / 0.6$ umol $^{-1}$; Kattegat surface: nitrate $=6.4 \mathrm{I}$ $1.7 \mu \mathrm{mol} \mathrm{l} \mathrm{l}^{-1}$, silicate $=5.8 / 1.5 \mu \mathrm{mol} \mathrm{l}^{-1}$, phosphate $=$ $0.8 / 0.6 \mu \mathrm{mol} \mathrm{l} \mathrm{l}^{-1}$ ). The fact that these nutrients were meaurable suggests that they were not limiting on either side of the front before or during the spring bloom in 1990. (The decline of the spring bloom in surface waters may, however, be related to the availability of nitrate in as much as concentrations of this nutrient fall to below the level of detection at the time of the bloom's decline; see Fig. 9.) Further work examining the relationship between the spring bloom and frontal activity in the Kattegat is clearly needed.

A number of studies in addition to the present have suggested that nitrogen availability is limiting for primary production in surface waters during summer in the Kattegat (Granéli 1984, 1987, Larsson 1988). If we assume that the annual primary production $(290 \mathrm{~g} \mathrm{C}$ $\mathrm{m}^{-2}$ ) occurring at the fixed station in the Kattegat is typical for the Kattegat and Belt Seas as a whole (area = $38000 \mathrm{~km}^{2}$ ), then the total annual primary production for this area can be estimated to be ca $1 \times 10^{7}$ t $\mathrm{C}$ in 1989 . Application of the Redfield ratio ( $\mathrm{C} / \mathrm{N}=5.68$ by weight) indicates a concomitant requirement for $1.8 \times 10^{6} \mathrm{t} \mathrm{N}$.

The net annual input of total dissolved $\mathrm{N}$ from all sources to the Kattegat/Belt Seas has been estimated to be $1.5 \times 10^{5} \mathrm{t}$ (Anon. 1987). In addition to the transport of $\mathrm{N}$ to the Kattegat/Belt Sea system, there exists a 'pool' of nitrogen already within the system. 
Winter dissolved inorganic $N$ concentrations in the Kattegat are ca $140 \mu \mathrm{g} \mathrm{l}^{-1}$. From this, a 'pool' size in this region of ca $10^{5} \mathrm{t} N$ can be estimated. Thus, only $2.5 \times$ $10^{5} \mathrm{t} N$ can be accounted for while the primary production estimate indicates that $1.8 \times 10^{6} \mathrm{t} \mathrm{N}$ are required to support production.

There are at least 3 possible explanations for this discrepancy:

(1) Annual primary production (ca $290 \mathrm{~g} \mathrm{C} \mathrm{m}^{-2} \mathrm{yr}^{-1}$ ) can be overestimated. This, however, seems unlikely as independent estimates (G. Ertebjerg unpubl.) are of a similar order of magnitude. In addition, the eutrophied state of the Kattegat would argue against an annual primary production rate of only ca $40 \mathrm{~g} \mathrm{C} \mathrm{m}^{-2} \mathrm{y}^{-1}$ which is the maximum that can be supported with the calculated available N. Already in the 1950s Steemann Nielsen recorded values of annual primary production at a station in the mid-Kattegat ('Anholt Nord') of between 70 and $110 \mathrm{~g} \mathrm{C} \mathrm{m}^{-2} \mathrm{y}^{-1}$ (data presented in Svansson 1975). The oxygen depletion events of recent years suggest higher primary production rates now than in the 1950 s.

(2) The input of $\mathrm{N}$ to the system may be underestimated. This explanation also seems unlikely as the nitrogen balance for the Kattegat/Belt Seas has been critically examined by a number of workers and interest groups in connection with the anoxia problem experienced in recent years in this area and all estimates are of the same order of magnitude (i.e. Sehested Hansen et al. 1991). The primary production occurring in the Kattegat, according to the arguments presented in this paper, require on the order of $7 \times$ the amount of nitrogen which is apparently transported to the Kattegat.

(3) The most likely explanation for the discrepancy between the $\mathrm{N}$ required to support the primary production occurring in the Kattegat/Belt Seas and the total available $N$ is that much of the $N$ used to support production is recycled within the system. Thus, some or all of the $N$ entering the system is used a number of times during a given year.

Further work is required in order to test this hypothesis. However, the above considerations demonstrate that the magnitude of the primary production occurring in the Kattegat/Belt Seas cannot be explained by the known inputs of nitrogen to this area. If recycling of nutrients within the system is the explanation for the discrepancy between the estimated primary production and input of nitrogen to this region, then it seems unlikely that all nitrogen entering the system enters the production cycle an equal number of times. Nitrogen in the system during winter or early spring when phytoplankton is not nutrient limited would be in less demand than that within the system in late spring and summer when there is evidence of nutrient depletion within the phytoplankton community.

In order to progress in our understanding of eutrophication related processes in the Kattegat/Belt Seas and the impact of various nutrient sources on the plankton dynamics in this region, it will be necessary in the future to examine the fate of the nutrients entering the system at different depths and at different times of the year and to combine this knowledge with studies of nutrient utilization and turnover rates at different times of the year.

Acknowledgements. We thank O. Vagn Olsen, Danish Institute for Fisheries and Marine Research and G. Ertebjerg Nielsen, Danmarks Miljøundersøgelser for access to their nutrient data.

\section{LITERATURE CITED}

Anon. (1987). Kvælstof og fosfor i vandmiljøet: konsensusrapport. Planlagningsrådet for Forskningen, Forskningssekretariat, Copenhagen, Denmark

Astheimer, H. Haardt, H. (1984). Small-scale patchiness of the chlorophyll fluorescence in the sea: aspects of instrumentation, data processing, and interpretation. Mar Ecol. Prog. Ser. 15: 233-245

Granéli, E. (1984). Algal growth potentjal and limiting nutrients for phytoplankton production in Oeresund water of Baltic and Kattegat origin. Limnologica 15(2): 563-569

Granéli, E. (1987). Nutrient limitation of phytoplankton biomass in a brackish water bay highly influenced by river discharge. Estuar coast. Shelf Sci. 25: 555-565

Grasshoff, K. (1976). Methods of seawater analysis. Verlag Chemie, Weinheim, New York

Heath, M. R., Richardson, K., Kiorboe, T (1990). Optical assessment of phytoplankton nutrient depletion. J. Plankton Res. 12: 381-396

Larsson, U. (1988). Kvæve och fosfor som biomassabegrænsande æmnen i havet. Vatten, 44: 19-28

Li, W. K. W., Goldman, J. C. (1981), Problems in estimating growth rates of marine phytoplankton from short-term ${ }^{14} \mathrm{C}$ assays. Microbiol. Ecol. 7- 113-121

Nicolaisen, W., Christensen, H. (1986). Pelagic turnover and transport to the bottom of particulate organic material in the northern Oresund. Ophelia 26: 317-332

Nicolajsen, H., Mohlenberg, F., Kiorboe, T (1983). Algal grazing by the planktonic copepods (Centropages hamatus and Pseudocalanus sp.): diumal and seasonal variation during the spring phytoplankton bloom in the Oresund. Ophelia 22: 15-31

Nielsen, T G., Kiorboe, T., Bjornsen, P. K. (1990). Effects of a Chrysochromulina polylepis subsurface bloom on the planktonic community. Mar Ecol. Prog. Ser. 62: 21-35

Peterson, B. J. (1980). Aquatic primary productivity and the ${ }^{14} \mathrm{CO}_{2}$ method: a history of the productivity problem. Ann. Rev. Ecol. Syst. 11. 369-385

Richardson, K. (1985). Plankton distribution and acitivity in the North Sea/Skagerrak-Kattegat frontal area in April, 1984. Mar. Ecol. Prog. Ser 26: 233-244

Richardson, K. (ed.) (1987). Primary production: quidelines for measurement by ${ }^{14} \mathrm{C}$ incorporation. Techniques in Marine Environmental Science No. 5. ICES, Copenhagen

Richardson, K. (1991). Comparison of ${ }^{14} \mathrm{C}$ primary production determinations made by different laboratories. Mar Ecol. Prog. Ser 72: 189-201 
Richardson, K., Samuelsson, G., Hällgren, J.-E. (1984). The relationship between photosynthesis measured by ${ }^{14} \mathrm{C}$ incorporation and by uptake of inorganic carbon in unicellular algae. J. exp. mar Biol. Ecol. 81: 241-250

Sehested Hansen, I., Pedersen, F. Bo, Jörgensen, L. A, Ertebjerg, G. (1991). Analyse af iltsænkning i Kattegat, Bælthavet og vestige Østersö. Hav-90 project, Miljostyrelsen, Copenhagen, Report no. 1

This article was submitted to the editor
Strickland, J. D. H., Parsons, T R. (1972). A practical handbook of seawater analysis. Bull. Fish. Res. Bd Can. 167

Svansson, A. (1975). Physical and chemical oceanography of the Skagerrak and the Kattegat. I. Open sea conditions Fish. Bd Swe. Inst. Mar. Res. Rep. No. 1

Watson, R. A., Osborne, P. L. (1979). An algal pigment ratio as an indicator of the nitrogen supply to phytoplankton in three Norfolk broads. Freshwat. Biol. 9: 585-594

Manuscript first received: September 17, 1990

Revised version accepted: September 17, 1991 